\title{
Mapping the health indicators of Chhattisgarh: A public health perspective
}

\section{Abhiruchi Galhotra, Gouri Ku. Padhy, Anjali Pal, Anjan K. Giri, Nitin M. Nagarkar ${ }^{1}$}

Department of Community and Family Medicine, ${ }^{1}$ Director, All India Institute of Medical Sciences, Raipur, Chhattisgarh, India

Address for the Correspondence:

Dr. Abhiruchi Galhotra, Additional Professor, Department of Community and Family Medicine, All India Institute of Medical Sciences, Raipur, Chhattisgarh, India.

E-mail: abhiruchigalhotra@ gmail.com

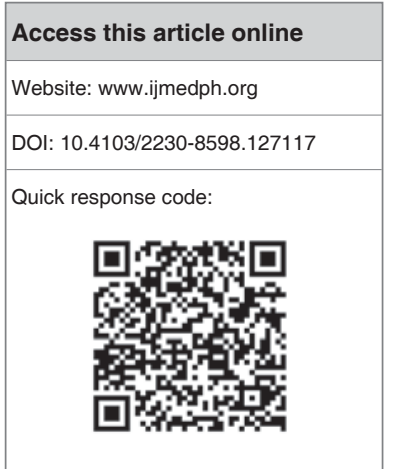

Introduction: The state of Chhattisgarh today faces several challenges in improving the health status of its people. The on-going problems of maternal and child mortality, communicable diseases, and HIV/AIDS pandemic still need greater interventions/support from the already overburdened health systems. In addition, the public health challenges include the escalating burden of chronic noncommunicable diseases. Keeping all these things in mind a study was carried out to have an overview of the public health scenario of Chhattisgarh. Aim: This paper aims to review the different public health indicators of Chhattisgarh. Materials and Methods: This study comprised of reviewing different health indicators of Chhattisgarh adopting three different methods during the period March-April 2013. The methods were: (i) extensive online search, (ii) reviewing the related literatures from different journals and other authentic printed materials, and (iii) information collected from public health experts through e-mail, telephone, or direct interaction. Results: Out of 2.55 crore populations in the state (as per Census 2011), $78 \%$ lives in rural areas and $37 \%$ of the population is tribal. The sex ratio is 968 and the literacy rate is $65.5 \%$ in population above 7 years of age. There is a shortage of trained health care providers in Chhattisgarh. The crude birth rate is 23.5 per 1000 (population Annual Health Survey [AHS] 2011-2012). The infant mortality rate is 48 per 1000 live births (SRS 2012). Malnutrition, anemia, sickle cell hemoglobinopathy, Beta thalassemia trait, and G6 PD enzyme deficiency are very high among the tribes of Chhattisgarh. Malaria has been a major health problem. Chhattisgarh is one of the states with annual parasite index > 5 (MRC report). The other states are Rajasthan, Gujarat, Karnataka, Goa, Southern Madhya Pradesh, Jharkhand, Odisha, and Northeastern states. Conclusion: From a public health point of view, most of the health indicators are below national average and unsatisfactory. The human resources gap, poor physical infrastructure, inadequate health education and awareness, poor health-seeking behavior, and inadequate healthcare utilization compound the problem. Indicators related to health and health care delivery are outcomes of research in diverse fields other than the department of health. Putting them together and projecting them in a public health view point encourage others to focus on the neglected indicators/areas. However, further research is needed to have a clear database in this regard.

Key words: National family health survey (NFHS-3), national rural health mission (NRHM), public health challenges

\section{INTRODUCTION}

Nobel laureate economist Amartya Sen is of the view that the health achievements of a given society are a better signal of social well-being than any conventional macroeconomic measure. ${ }^{[1]}$ Public health is one of the best indicators of a nation's overall growth and development, no matter how big/small, how developed or undeveloped a country is, it speaks of past, present, and future of its generations. ${ }^{[2]}$ Health of the people is an essential requirement for accelerated economic growth of a country/state.

Chhattisgarh state was carved out of erstwhile Madhya Pradesh state in 2000. The state of Chhattisgarh has an area of 1,35,191 sq. km. and a population of 25.5 million. ${ }^{[3]}$ The State has population density of 154 per sq. $\mathrm{km}$. (as against the national average of 312). ${ }^{[4]}$ It ranks as the $16^{\text {th }}$ most-populated state of the nation. It is an important electricity and steel-producing state of India. There are 27 districts, 146 blocks, and 20,308 villages. More than half of these districts have been classified as remote, tribal, and extremist affected areas (one-third of Chhattisgarh's 
population is of tribes). ${ }^{[5]}$ Chhattisgarh is currently facing several challenges in improving the health and nutritional status of its people. The newer public health challenges include the escalating burden of chronic noncommuncable diseases leading to an epidemiological transition. The rising elderly population is leading to a demographic transition. Environmental factors and climate changes also have an impact on the disease patterns. Concurrently, the ongoing problems of maternal and child mortality, communicable diseases, and HIV/AIDS pandemic still need greater interventions/support from the already overstretched and overburdened health systems. Keeping all these things in mind, a study was carried out to get an overview of the public health scenario of Chhattisgarh. The aim of this study is to review the public health scenario of Chhattisgarh.

\section{MATERIALS AND METHODS}

The study was a brief review of public health scenario of Chhattisgarh carried out in the month of March 2013. The steps followed for collection of data are mentioned below. The data regarding the public health scenario of the state was obtained using three methods. A systematic, predefined approach was used for obtaining this information. All these three steps were carried out simultaneously.

- The first method comprised of using the information available on the Internet. The internet search was conducted using the Google search engine to collect information from various national and state level survey reports (NFHS-3, DLHS-3, and AHS-10/11). The website of the govt of Chhattisgarh was also accessed. $^{[5]}$

- The second search method involved a detailed literature review of the health scenario of Chhattisgarh from various online journals.

- The third method involved was contacting experts in the field of public health in Chhattisgarh. "Expert" here implies those persons holding a post in the state/district level who were directly dealing with public health issues. The majority of them were having a qualification of MD in Community Medicine. Others had a medical degree with a public health work background. These were done through e-mail and/or telephone/face-to-face interaction. They were requested to share information regarding this issue.

\section{RESULTS}

\section{Background characteristics}

The total population of Chhattisgarh is 2.55 crore (Census 2011). ${ }^{[3]}$ Of them, $78 \%$ of the population live in rural areas, ${ }^{[6]}$ and $34.1 \%$ of the population is below 15 years. ${ }^{[7]}$ The sex ratio for the State as a whole is 968 (975 in rural area and 944 in urban areas) (AHS 2010-11). The sex ratio at birth is 951, 0-4 year sex ratio is 978. ${ }^{[8]}$ Of them, $93 \%$ of the households are Hindus, $5 \%$ Christians, $1 \%$ Muslims, and 1\% other religions. Mainly, Jains and Muslims are more concentrated in the urban areas where they comprise 5\% whereas Christians are more concentrated in the rural areas where they comprise $6 \%$ of the households. Of the total population, $37 \%$ are (tribal) schedule tribes, $39 \%$ OBCs, $15 \%$ schedule caste, and $9 \%$ do not belong to any of the groups (NFHS-2).

Table 1 shows the population and household profile of Chhattisgarh. Of the total population, $71 \%$ of the households have electricity. The mean household size is 5 . Only $14.4 \%$ have piped water supply and only $17 \%$ have toilet facility, $65.5 \%$ of population age 7 and above are literate. ${ }^{[7]}$

\section{Health human resources and health care infrastructure}

Tables 2 and 3 reflect the status of health human resources and health care infrastructure. ${ }^{[4]}$ There is a shortage of trained health care providers in Chhattisgarh. About one-third of the subcenters do not have a single Auxillary Nurse Midwife $(\mathrm{ANM})$ as against the allocation of two ANMs. The shortfall for doctors both MBBS graduates and specialists is about $72 \%$. The shortfall in doctors is more perceived/apparent in the rural areas as majority of the doctors are based in urban and semiurban areas. ${ }^{[4]}$

\section{Marriage, fertility, family planning, and reproductive health care}

Table 4 reflects indicators related to marriage and fertility. Daughters in Chhattisgarh are generally married off at an early age. The mean age at marriage among women is 18.9 years and for men it is 22.8 years. About $21.3 \%$ of women and $29.1 \%$ of men in Chhattisgarh marry before they reach the legal minimum age at marriage of 18 and 21 years, respectively. ${ }^{[6]}$ The crude birth

\begin{tabular}{|c|c|c|c|c|c|c|}
\hline \multirow[t]{2}{*}{ Indicator } & \multicolumn{3}{|c|}{ Chhattisgarh } & \multicolumn{3}{|c|}{ India } \\
\hline & $\begin{array}{c}\text { Total } \\
(\%)\end{array}$ & $\begin{array}{c}\text { Rural } \\
(\%)\end{array}$ & $\begin{array}{c}\text { Urban } \\
(\%)\end{array}$ & $\begin{array}{l}\text { Total } \\
\text { (\%) }\end{array}$ & $\begin{array}{c}\text { Rural } \\
(\%)\end{array}$ & $\begin{array}{c}\text { Urban } \\
(\%)\end{array}$ \\
\hline \multicolumn{7}{|l|}{ Population profile } \\
\hline $\begin{array}{l}\text { Population literate } \\
\text { age } 7+\text { years }\end{array}$ & 65.7 & 62.2 & 82.7 & 72.2 & 67.2 & 82.9 \\
\hline $\begin{array}{l}\text { Population literate } \\
\text { age } 15 \text { years }\end{array}$ & 34.1 & 35.0 & 29.4 & 32.6 & 34.4 & 28.8 \\
\hline $\begin{array}{l}\text { Mean house hold } \\
\text { size }\end{array}$ & 5.0 & 5.1 & 4.1 & 5.1 & 5.2 & 4.9 \\
\hline \multicolumn{7}{|c|}{ Percentage of household that } \\
\hline Have electricity & 71.2 & 66.3 & 95.3 & 70.3 & 59.8 & 92.2 \\
\hline $\begin{array}{l}\text { Have access to toilet } \\
\text { facility }\end{array}$ & 17.9 & 9.8 & 57.1 & 49.3 & 34.1 & 80.8 \\
\hline $\begin{array}{l}\text { Live in a Kachcha } \\
\text { house }\end{array}$ & 75.6 & 83.9 & 34.4 & 35.5 & 46.4 & 12.9 \\
\hline $\begin{array}{l}\text { Live in a Pucca } \\
\text { house }\end{array}$ & 10.5 & 4.5 & 39.5 & 32.7 & 19.6 & 60.2 \\
\hline $\begin{array}{l}\text { Use piped drinking } \\
\text { water }\end{array}$ & 14.4 & 4.1 & 65.2 & 84.4 & 79.6 & 94.4 \\
\hline
\end{tabular}




\begin{tabular}{|c|c|c|c|c|}
\hline \multirow[t]{3}{*}{ HR status } & \multicolumn{4}{|c|}{ Chhattisgarh } \\
\hline & \multirow[t]{2}{*}{ Required } & \multicolumn{2}{|c|}{ In position } & \multirow[t]{2}{*}{ Gap } \\
\hline & & Regular & Contractual & \\
\hline $\begin{array}{l}\text { Doctors } \\
\text { (allopathic) }\end{array}$ & 2365 & 1014 & 158 & 1193 \\
\hline $\begin{array}{l}\text { AYUSH } \\
\text { doctors }\end{array}$ & 1092 & 759 & 325 & 8 \\
\hline Specialists & 928 & 245 & 0 & 683 \\
\hline Paramedics & 6092 & 3985 & 312 & 1795 \\
\hline Staff nurses & 5000 & 749 & 400 & 3851 \\
\hline $\begin{array}{l}\text { Lady Health } \\
\text { Visitor }\end{array}$ & 1084 & 749 & 0 & 335 \\
\hline Pharmacists & 1100 & 733 & 0 & 367 \\
\hline
\end{tabular}

1287 Rural edical Assistant working in CHCs and PHCs.

\begin{tabular}{lc} 
Table 3: Health care infrastructures of \\
Chhattisgarh as per the $5^{\text {th }}$ & CRM report \\
\hline Number of facilities functioning & Chhattisgarh \\
\cline { 2 - 2 } & As on 31/03/2011 \\
\hline District hospitals & 17 \\
CHC & 148 \\
PHC & 741 \\
Subcenter & 5076 \\
Blood storage units & $18 / 39$ \\
Blood banks & $14 / 17$ \\
Special newborn care units & $1 / 9$ \\
(SNCUs) & \\
NBSU (new born stabilization unit) & 15 \\
NBCC (new born care corner) & 48 \\
Bed population ratio & 0.48 \\
\hline
\end{tabular}

rate is 23.5 per 1000 population (rural 24.4 and urban 20.2 as per Annual Health Survey Statistics 2011-2012 with crude death rate 7.4 per thousand population (rural 7.8; urban 6.0). The natural growth rate is 16.1 (rural 16.7; urban 14.3). ${ }^{[8]}$ Many women in Chhattisgarh are not using family planning, even though knowledge of contraception is nearly universal. Contraceptive prevalence in Chhattisgarh is $49.7 \%$. About $41.3 \%$ of currently married women are sterilized. In contrast, only $1.8 \%$ husbands are sterilized; The use rate for Oral Contraceptive (OC) pill is only 1.7\%, Intra Uterine Devices $0.6 \%$, and condom $1.6 \% .{ }^{[7]}$ The Maternal Mortality Rate of Chhattisgarh is $269 .{ }^{[9]}$

\section{Infant and child mortality}

The infant mortality rate is 48 per 1000 live births, which is high in comparison to the other developed states of the country. The neonatal mortality rate is 35 per 1000 live births (rural, 37; urban, 29) ${ }^{[10]}$ and under 5 the mortality rate is 61 per 1000 live births. ${ }^{[1]}$ Chhattisgarh has made some progress toward achieving MDGs over the last few years, but it has still a long way to go for achieving the millennium development goals.

\section{Reproductive health}

Promotion of maternal and child health has been one of the most important components of the Family Welfare Program. Each pregnant woman should receive at least three antenatal care checkups and two tetanus toxoid injections and a full course of iron and folic acid supplementation. In Chhattisgarh, mothers of $79.6 \%$ of children had received at least one antenatal checkup (51.2\% had three ANC), $37.9 \%$ of mothers consumed 100 tablets of iron and folic

\begin{tabular}{|c|c|c|c|c|c|c|}
\hline \multirow[t]{2}{*}{ Indicator } & \multicolumn{3}{|c|}{ Chhattisgarh } & \multicolumn{3}{|c|}{ India } \\
\hline & Total (\%) & Rural (\%) & Urban (\%) & Total (\%) & Rural (\%) & Urban (\%) \\
\hline \multicolumn{7}{|l|}{ Indicators related to marriage as per DLHS-3 } \\
\hline Mean age at marriage, boys & 22.8 & 22.2 & 25.1 & 24.0 & 23.4 & 25.5 \\
\hline Mean age at marriage, girls & 18.9 & 18.7 & 20.5 & 19.8 & 19.2 & 21.2 \\
\hline Boys married below age 21 years & 29.1 & 32.3 & 14.0 & 23.4 & 28.4 & 12.6 \\
\hline Girls married below age 18 years & 21.3 & 23.0 & 12.3 & 22.1 & 26.9 & 11.0 \\
\hline \multicolumn{7}{|l|}{ Indicators related to fertility as per NFHS-3 } \\
\hline Total fertility rate & 2.62 & 2.88 & 1.78 & 2.7 & 3.0 & 2.1 \\
\hline $\begin{array}{l}\text { Women age } 15-19 \text { who were already mothers or } \\
\text { pregnant at the time of the survey }\end{array}$ & 14.6 & 16.5 & 7.6 & 16.0 & 19.1 & 8.7 \\
\hline $\begin{array}{l}\text { Median age at the first birth for women age } \\
25-49 \text { years }\end{array}$ & 18.8 & 18.5 & 20.0 & 19.8 & 19.3 & 20.9 \\
\hline $\begin{array}{l}\text { Married women with two living children wanting } \\
\text { no more children }\end{array}$ & 75.3 & 71.2 & 87.2 & 84.6 & 81.6 & 89.7 \\
\hline \multicolumn{7}{|l|}{ Use of family planning method as per DLHS-3 } \\
\hline Contraceptive use (any method) & 49.7 & 47.8 & 59.2 & 54.0 & 51.1 & 60.2 \\
\hline Female sterilization & 41.3 & 41.0 & 43.3 & 34.0 & 34.1 & 34.6 \\
\hline Male sterilization & 1.8 & 1.9 & 1.1 & 1.0 & 1.0 & 0.7 \\
\hline Pill & 1.7 & 1.4 & 3.3 & 4.2 & 4.1 & 4.4 \\
\hline IUD & 0.6 & 0.3 & 1.9 & 1.9 & 1.4 & 2.9 \\
\hline Condom & 1.6 & 0.9 & 5.7 & 5.9 & 3.8 & 10.6 \\
\hline
\end{tabular}


acid supplementation. Table 5 shows indicators related to antenatal and delivery care.

\section{Nutrition of children and women}

It is recommended that breastfeeding should begin immediately after birth and that infants should be exclusively breastfed for the first 6 months of life. Although breastfeeding is nearly universal in Chhattisgarh, most children do not begin breastfeeding immediately after birth. Only $50.1 \%$ begin breastfeeding in the first hour. Further, $78.3 \%$ of $0-6$ month babies are exclusively breast fed. At age 6-9 months, all children should receive solid or mushy food in addition to breast milk. Only $56.8 \%$ of children of age 6-9 months received the recommended combination of breast milk and solid or mushy foods. Nutritional status is a major determinant of health and wellbeing among children. Developing countries like India account for almost half of the undernourished children in the world and this is largely due to dietary deficiency in relation to the nutritional needs. Malnutrition is prevalent in the State on a large scale. Nutritional deficiency is more prevalent in Chhattisgarh in rural areas and among SC and ST women and illiterate women. Anemia is a serious problem among women in Chhattisgarh. Table 6 shows malnutrition and anemia prevalence of Chhattisgarh state. About $41.0 \%$ women and $31.8 \%$ men had body mass index below normal. Moreover, $57.6 \%$ of ever-married women and $26.4 \%$ ever-married men of age $15-49$ in Chhattisgarh are anemic (63.1\% of pregnant women are anemic). Numbness and tingling of hands and feet due to vitamin B1 deficiency is very common. ${ }^{[12]}$

\section{Children's immunization}

Immunization of children is aimed at preventing diseases and inducing a herd immunity which may help them grow in a healthier environment. Table 7 reflects the immunization status of children. In Chhattisgarh, only $21.8 \%$ of children age $12-23$ months were fully vaccinated as per NFHS-2 and this proportion improved to $48.7 \%$ in $2005-2006$ (NFHS-3). It further improved to $59.3 \%$ in DLHS-3 and $74.1 \%$ in AHS 2011. Although 94.8\% had received BCG vaccination, only $79.9 \%$ children received measles vaccine, 71.4 received all three doses of DPT. About $2.4 \%$ of children had not received any vaccine. The dropout rates are very high for the vaccinations ( $94.8 \%$ for BCG to $71.4 \%$ for DPT). Children under 5 years of age should receive oral doses of vitamin A every 6 months starting at the age of 9 months. Only $65.1 \%$ of children (age 9 months and above) in Chhattisgarh had received at least one dose of vitamin A supplementation.

\begin{tabular}{|c|c|c|c|c|c|c|}
\hline \multirow[t]{2}{*}{ Indicator } & \multicolumn{3}{|c|}{ Chhattisgarh } & \multicolumn{3}{|c|}{ India } \\
\hline & Total (\%) & Rural (\%) & Urban (\%) & Total (\%) & Rural (\%) & Urban (\%) \\
\hline \multicolumn{7}{|l|}{ Antenatal care } \\
\hline Mothers who received any ANC & 79.6 & 77.7 & 92.1 & 75.2 & 70.6 & 87.1 \\
\hline Mothers who had ANC in the first trimester & 38.6 & 33.9 & 68.2 & 45.0 & 38.5 & 61.8 \\
\hline Mothers who had 3 or more ANC & 51.2 & 47.3 & 75.9 & 49.8 & 44.1 & 69.1 \\
\hline Mothers who had at least one TT injection & 78.0 & 76.0 & 90.8 & 73.4 & 68.7 & 85.6 \\
\hline Mothers whose BP taken (\%) & 39.1 & 34.3 & 68.9 & 45.7 & 38.0 & 65.8 \\
\hline Mothers who consumed 100 IFA tablets & 20.8 & 19.9 & 26.8 & 46.6 & 47.3 & 45.0 \\
\hline Mothers who had full ANC & 13.0 & 11.3 & 24.0 & 18.8 & 14.7 & 29.4 \\
\hline \multicolumn{7}{|l|}{ Delivery care } \\
\hline Institutional delivery & 18.1 & 13.2 & 48.4 & 47.0 & 37.9 & 70.5 \\
\hline Home delivery & 81.6 & 86.3 & 51.3 & 52.3 & 61.3 & 29.0 \\
\hline Mothers who received PNC within 2 weeks of delivery & 41.6 & 38.0 & 64.6 & 49.7 & 41.7 & 69.7 \\
\hline
\end{tabular}

\begin{tabular}{|c|c|c|c|c|c|c|}
\hline \multirow[t]{2}{*}{ Indicator } & \multicolumn{3}{|c|}{ Chhattisgarh } & \multicolumn{3}{|c|}{ India } \\
\hline & Total (\%) & Urban (\%) & Rural (\%) & Total (\%) & Urban (\%) & Rural (\%) \\
\hline \multicolumn{7}{|c|}{ Nutritional status of ever-married adults (age 15-49) and children } \\
\hline Women whose body mass index is below normal & 41.0 & 23.5 & 45.7 & 33.0 & 19.8 & 38.8 \\
\hline Men whose body mass index is below normal & 31.8 & 17.9 & 35.6 & 28.1 & 17.5 & 33.1 \\
\hline Children under 3 years who are stunted & 45.4 & 32.8 & 47.9 & 44.9 & 37.4 & 47.2 \\
\hline Children under 3 years who are wasted & 17.9 & 17.7 & 17.9 & 22.9 & 19.0 & 24.1 \\
\hline Children under 3 years who are underweight & 52.1 & 38.9 & 54.6 & 40.4 & 30.1 & 43.7 \\
\hline \multicolumn{7}{|l|}{ Anemia among children and adults } \\
\hline Children age 6-35 months who are anemic & 81.0 & 75.6 & 82.1 & 78.9 & 72.2 & 80.9 \\
\hline Ever-married women age $15-49$ who are anemic & 57.6 & 50.3 & 59.4 & 56.2 & 51.5 & 58.2 \\
\hline Pregnant women age $15-49$ who are anemic & 63.1 & 65.2 & 62.7 & 57.9 & 54.6 & 59.0 \\
\hline Ever-married men age $15-49$ who are anemic & 26.4 & 17.9 & 28.7 & 24.3 & 17.2 & 27.7 \\
\hline
\end{tabular}




\begin{tabular}{|c|c|c|c|c|c|c|}
\hline \multirow[t]{2}{*}{ Indicator } & \multicolumn{3}{|c|}{ Chhattisgarh } & \multicolumn{3}{|c|}{ India } \\
\hline & Total (\%) & Rural (\%) & Urban (\%) & Total (\%) & Rural (\%) & Urban (\%) \\
\hline Children $12-23$ months fully immunized & 59.3 & 57.2 & 71.4 & 54.0 & 50.4 & 63.1 \\
\hline Children $12-23$ months not received any vaccination & 4.2 & 4.4 & 3.2 & 4.5 & 5.2 & 2.9 \\
\hline Children 12-23 months who have received BCG & 94.8 & 94.4 & 96.8 & 86.7 & 85.2 & 90.4 \\
\hline Children $12-23$ months who received three doses of DPT & 71.4 & 70.0 & 80.1 & 63.5 & 60.1 & 72.2 \\
\hline Children $12-23$ months who received three doses of polio & 69.7 & 68.1 & 78.3 & 66.0 & 63.1 & 73.7 \\
\hline Children 12-23 months who have received measles & 79.9 & 79.1 & 84.4 & 69.5 & 66.5 & 77.5 \\
\hline $\begin{array}{l}\text { Children (age } 9 \text { months and above) received at least one } \\
\text { dose of vitamin-A }\end{array}$ & 65.1 & 64.1 & 71.4 & 54.5 & 52.0 & 61.1 \\
\hline
\end{tabular}

\section{Morbidity}

Although the state has progressed a lot in the field of health, it still has a long way to go. Communicable diseases such as diarrhoea, malaria, leprosy, and tuberculosis still present a major health problem in the State. Measles still contributes to child mortality in the state.

Tribal communities in India, in general and of Chhattisgarh state in particular, are highly vulnerable to various genetic diseases, nutritional deficiencies, and unhealthy social practices such as consanguineous marriages. The frequency of sickle cell hemoglobinopathy (3.2$22.5 \%)$, Beta thalassemia trait (0.5-8.5\%), and G6 PD enzyme deficiency $(6-16 \%)$ is very high among the tribes of Chhattisgarh. ${ }^{[13]}$

Malaria has been a major health problem in the state. Due to varied ecological conditions and geography, the bulk of the burden of malaria is borne by the tribal of the forested area in the north and the south. In 2006 , Chhattisgarh contributed $7 \%$ of the total malaria cases and $11 \%$ of the P. falciparum cases reported in the country (NVBDCP, 2007). As per the available data on malaria, the central part of the state (represented by eight districts having $61.09 \%$ of the state's population) reports low-to-moderate incidence of malaria $(8.16 \%)$ and P. falciparum (4.58\%). The rest of the malaria burden is collectively contributed by the five districts in the north and three districts in the south. The problem is further compounded by the reports of chloroquine resistance in P. falciparum from Surguja, Kanker, and Bastar districts. There are 93 PHCs in the state with a population of 83 lakhs that have API of 2 and above and are declared as high risk. The major vector control strategy includes indoor residual spraying with DDT in 13 Districts and that with synthetic pyrethroid in three districts namely Jagadalpur, Dantewada, and Kanker. ${ }^{[12]}$ The areas where the tribes reside are hyper-endemic for malaria. The slide positivity rate is as high as $15.6 \%$ for $P$. falciparum. ${ }^{[13]}$

While reviewing the morbidity and mortality pattern due to different diseases, it was observed that 51,480 diarrheal cases with two deaths, 38,532 cases of enteric fever, 107,827 cases of ARI with 7 deaths, 16 cases of neonatal death, 13 cases of tetanus with one death, 258 cases of diphtheria, 927 cases of whooping cough, 89 cases of measles, 287 cases of viral hepatitis with 4 death, 50 cases of H1N1 influenza with 12 death, 207, 959 cases of major and 1,049,795 cases of minor mental illnesses, 22,255 deaths due to natural calamity and 3,34,766 deaths due to accidents were reported from Chhattisgarh in the year 2010. The AFP rate was 3.81 (non-polio AFP 3.08). ${ }^{[14]}$ The HIV prevalence rate for 2008 was 0.25 , and 3692 cases received ART from 4 ART centers in 2010. According to NACO 2006, the Durg district has the maximum HIV burden and Bastar the second highest. ${ }^{[15]}$ Use of any form of tobacco in men and women was found to be $68.6 \%$ and $25.2 \%$, respectively (smoking prevalent in $31.8 \%$ men and $0.2 \%$ women). ${ }^{[14]} \mathrm{A}$ total of 82,275 suspected cases of tuberculosis were detected in 2011-2012. The sputum positive rate was $12 \%$ and the annual case detection rate was $116 /$ lakh. The sputum conversion rate after 3 months was $88 \%$, with $80 \%$ cure rate and $87 \%$ success rate. The annual new case detection rate for leprosy was 32.20 per 1,00,000 population, and the prevalence rate was 2.24 per 10,000 population. ${ }^{[4]}$

In Chhattisgarh, there is widespread prevalence of domestic violence. About 30\% of ever-married women have experienced spousal violence. Most of these women have been beaten or physically mistreated by their husbands. ${ }^{[6]}$

\section{DISCUSSION}

Women in Chhattisgarh have an average of 2.6 children throughout their childbearing years. Median age for first birth for women aged 25-49 years is 18.8. Government of India has been using electronic and other mass media to promote family planning. Exposure to mass media is fairly good in Chhattisgarh. About 65.5\% rural houses have electricity and $22.2 \%$ have TV (NFHS 3). In the total population, $69 \%$ of men and $52 \%$ of women of $15-49$ years have exposure to media (NFHS 3). Exposure to mass media promotion of family planning services is not sufficient to bring about a change in behavior for seeking family planning services with open mind. We also have to consider other approaches of behavior change communication which can even take care of those who are not having access to mass media.

MMR of Chhattisgarh is 269 as compared to 212 for India. ${ }^{[0]}$ Many women still die due to pregnancy-related causes. The AHS-2011 reports that $34.9 \%$ ever-married women had delivery in a hospital or other institutions as compared to $18 \%$ in DLHS 2007-2008. There are wide rural-urban differences in various health indicators between various districts as per the AHS. About $11.5 \%$ delivery conducted at home is assisted by a skilled health personnel. Only $41.6 \%$ of 
mothers had a postpartum checkup within 2 weeks of delivery. Utilization of $\mathrm{MCH}$ services in Chhattisgarh remains very low.

The family welfare programme and NRHM encourage women to deliver in a health facility or if at home with assistance from a trained health professional and to receive at least three postnatal checkups.

As per NFHS-2 in 1998-1999, 60.8\% of children under age 3 years in Chhattisgarh were underweight, $57.9 \%$ stunted, and $18.5 \%$ were wasted. In the year 2005-2006 (NFHS-3), the corresponding percentages are $52.1 \%, 45.4 \%$, and $17.9 \%$ are underweight, stunted, and wasted, respectively. This shows improvement in the nutritional level in 2005-2006 over 1998-1999. ${ }^{[16]}$ Anemia also presents a problem among the people specially the children of Chhattisgarh. About 87.7\% children aged 6-35 months were anemic in 1998-1999 and this proportion reduced to $81 \%$ in $2005-2006$. Female children are more likely to be anemic. The anemic tendencies are more among rural children (NFHS-2 and NFHS-3). ${ }^{[16]}$

Approximately $65-70 \%$ of the morbidity and mortality rates are consequences of preventable factors. Chhattisgarh does not have adequate number of key frontline health care providers and specialists, especially for maternal and child-health services. Chhattisgarh has pioneered innovative approach in health care delivery to rural masses. The well-known Mitanin scheme has been lauded all over the country and has been replicated. Other schemes such as "Rural Medical Assistant and Phulwari" have also been launched. A detailed review of health scenario will help in highlighting the priority areas for further actions.

\section{CONCLUSION}

As a predominant share of the population of Chhattisgarh being tribal, and because it was initially a part of a big state Madhya Pradesh, it was deprived of the gains of development process. The human resources gap, poor physical infrastructure, and other supply-side gaps compound the problem. There is poor community participation in public health interventions carried out by the government and the reasons for which are still to be unearthed. Chhattisgarh lacks economic and social infrastructure that if provided could boost economic growth. It lags behind the country as a whole on several socioeconomic and health indicators reflecting the critical need for improving access to public health services. There is also need for further research in these areas to provide the baseline data and also to identify the contributing factors/determinants that are responsible for the current public health scenario so that the corrective steps can be taken by the governmental and nongovernmental agencies accordingly.

\section{REFERENCES}

1. Subramanian SV,Ackerson LK, SubramanyamMA, Sivaramakrishnan K, Health Inequalities in India: The Axes of Stratification. Brown J World Aff 2008;14:127-38.

2. Miraj M, Ali S. Public Health Scenario in India: Challenges for the $21^{\text {st }}$ century.BiosciBiotechnol ResCommun2010;3:1-6. Available from: http:// www.bbrc.in/contents/jun2010/1.pdf [Last accessed on 2013 Mar 10].

3. Census of India, 2011, Registrar General of India, Government of India, 2011.

4. $\quad 5^{\text {th }}$ Common Review Mission, Chhattisgarh, 2011. Page no 7.

5. Available from: http://www.cg.gov.in/Archive. [Last accessed on 2013 Oct 10].

6. International Institute for Population Sciences (IIPS) and Macro International.National Family Health Survey (NFHS-3), India, 2005-06: Chhattisgarh. Mumbai: IIPS; 2008.

7. International Institute for Population Sciences (IIPS) District Level Household and Facility Survey (DLHS-3), 2007-08: India.Chhattisgarh: Mumbai: IIPS; 2010.

8. Annual Health Survey Bulletin 2011-2012; Chhattisgarh. Office of the Registrar General and Census Commissioner, India, GOI, Ministry of Home Affairs, Vital Statistics Division, New Delhi. Available from: http://www.censusindia.gov.in/vital_statistics/AHSBulletins/ files2012/Chhattisgarh_Bulletin\%202011-12.pdf. [Last accessed on 2013 Oct 11].

9. Govt. of India (2011).Special Bulletin on Maternal Mortality in India 20072009; Sample Registration System, June 2011.

10. SRS Bulletin, Vol. 47, no. 2. Registrar General, India, New Delhi, October 2012.

11. Trends in under five mortality rate-India and bigger states. Available from:http://data.gov.in/dataset/under-5-mortality-rate-u5mr. [Last accessed on 2013 Mar 11].

12. National Vector Borne Disease Control Programme: Epidemiological Situation of Chhattisgarh State for year 2005, 2006, 2007.Available from:http://mohfw.nic.in/NRHM/PIP_09_10/Chhattisgarh/NVBDCP_Text. pdf. [Last accessed on 2013 Mar 10].

13. Balgir RS. Genetic disease burden, nutrition and determinants of tribal health care in Chhattisgarh state of Central East India: A status paper. Online J Health Allied Sci 2011;10:4.

14. Available from: http://cbhidghs.nic.in/writereaddata/mainlinkfile/file1012 pdf. [Last accessed on 2013 Mar 13].

15. Singh H, Dulhani N, Bithika NK, Tiwari P, Chauhan VK, Singh P. Rural epidemiology of HIV positive tribal patients from Chhattisgarh in India. J Glob Infect Dis 2010;2:39-42.

16. Chhattisgarh and UN Millennium Development Goals (MDGs), Status and Progress at Half Way Mark, 2007. Available from:http://www.cgsird.gov.in/ Chattisgarh-20MD20Report.pdf. [Last accessed on 2013 Mar 15].

How to cite this article: Galhotra A, Padhy GK, Pal A, Giri AK, Nagarkar NM. Mapping the health indicators of Chhattisgarh: A public health perspective. Int J Med Public Health 2014;4:23-8.

Source of Support: Nil. Conflict of Interest: None declared. 